\title{
MODAL INTELEKTUAL DAN KINERJA KEUANGAN : KEUNGGULAN BERSAING SEBAGAI VARIABEL INTERVENING
}

\author{
Muhammad Fahri Azmi $^{1^{*}}$, Yusralaini Yusralaini ${ }^{2}$, Rofika Rofika ${ }^{3}$ \\ ${ }^{123}$ Program Studi Akuntansi, Fakultas Ekonomi dan Bisnis, Universitas Riau, Pekanbaru \\ *E-mail: muhammad.fahriazmi11@gmail.com
}

\begin{tabular}{l}
\hline Keywords \\
\hline Value Added Capital \\
Employed, \\
Value Added Human \\
Capital, \\
Structural Capital Value \\
Added, \\
Value Added Modal \\
Intelektual, \\
Competitive Advantage, \\
Financial Performance. \\
\hline
\end{tabular}

Article informations

Received:

2021-03-09

Accepted:

2021-07-19

Available Online:

2021-07-31

\begin{abstract}
This study aims to see the effect of VACA, VAHU, STVA, and VAIC on financial performance and competitive advantage, as well as the role of competitive advantage in mediating the effect of VACA, VAHU, STVA, and VAIC on financial performance. The population in this study is Islamic commercial banks registered with the financial services authority in 2016-2018. The sample of this research was selected by sampling criteria. Hypothesis testing used in this research is Structural Equation Modeling with Partial Least Square (SEM-PLS) approach and the statistical test tool used is WarpPLS 7.0. The results of this study indicate that VACA has a positive influence on financial performance, VAHU has a negative influence on financial performance while STVA and VAIC do not affect financial performance. Furthermore, this study found that VACA, STVA, and VAIC had a positive effect on competitive advantage and competitive advantage also has a positive effect on financial performance. This research also found that, while VAHU did not affect the competitive advantage that competitive advantage plays a role in mediating the effect of VACA and VAIC on financial performance, whereas competitive advantage does not mediate the effect of VAHU and STVA on financial performance.
\end{abstract}

\section{PENDAHULUAN}

Kinerja merupakan kondisi perusahan yang ditampilkan secara utuh selama periode waktu tertentu, dan merupakan hasil atau prestasi yang dipengaruhi oleh kegiatan operasional organisasi bisnis dalam menggunakan dan memanfaatkan sumber daya yang dimiliki dalam Helfert (1996). Kinerja keuangan merupakan kemampuan organisasi atau organisasi bisnis untuk memanfaatkan, mengelola dan mengendalikan sumber daya yang dimiliki organisasi bisnis tersebut dalam Ikatan Akuntan Indonesia (2007). Dalam menghadapi persaingan yang sangat ketat, organisasi bisnis dituntut untuk memperbaiki dan mempertahankan kinerja keuangannya agar dapat bersaing dengan organisasi bisnis lain. Cara yang bisa dilakukan oleh 
organisasi adalah dengan keunggulan kompetitif, yang berarti bahwa organisasi bisnis harus mempunyai sesuatu yang tidak ada pada para pesaing.

Dalam beberapa tahun terakhir penulis menemukan berita dari finansial.bisnis.com yang menyatakan PT. Bank Muamalat Indonesia mengalami penurunan kinerja kuangan, laba bank anjlok pada kuartal II/2019, ini menunjukkan kinerja organisasi bisnis tidak baik. Laba bersih setelah pajak bank per Juni 2019 merosot 95,1\% secara tahunan (year-on-year) menjadi Rp5,1 miliar. Berikut tabel perbankan syariah yang memiliki kinerja buruk:

\section{Tabel 1}

Data Perbankan Syariah yang Mengalami Kerugian dan Penurunan Laba

\begin{tabular}{clcc}
\hline No & \multicolumn{1}{c}{ Nama Organisasi bisnis } & $\begin{array}{c}\text { Laba 2016 } \\
\text { (dalam jutaan) }\end{array}$ & $\begin{array}{c}\text { Laba 2017 } \\
\text { (dalam jutaan) }\end{array}$ \\
\hline 1 & PT. Muamalat Indonesia & Rp80.511 & Rp26.116 \\
2 & PT. Bank BRI Syariah & Rp170.209 & Rp101.091 \\
3 & PT. Mega Syariah & Rp110.729 & Rp72.555 \\
4 & PT. Bank Jabar Banten Syariah & $-R p 414.714$ & - Rp383.428 \\
5 & PT. Bank Panin Dubai Syariah & Rp19.541 & -Rp968.851 \\
6 & PT. Maybank Syariah Indonesia & $-R p 163.738$ & -Rp9.785 \\
\hline
\end{tabular}

Sumber: Data Olahan (2020)

Berdasarkan tabel diatas ada 6 bank umum syariah dari 13 bank umum syariah yang mengalami kerugian dan penurunan laba, hal ini berbeda pada salah satu tujuan dari kebanyakan organisasi bisnis adalah memksimalkan keuntungan atau laba dalam Warren et al., (2013). Semakin besar banyak keuntungan yang dihasilkan organisasi bisnis akan semakin tinggi tingkat returnnya. Dengan tingkat pengembalian yang tinggi akan mendorong investor untuk berinvestasi lebih besar dari investasi sebelumnya sehingga dapat meningkatkan nilai jual saham dalam organisasi bisnis tersebut dalam Hidayat (2018).

Pada kasus lain ada beberapa Bank Umum Syariah yang mengalami penurunan return on assets (ROA). Penurunan ini menandakan bahwa Bank Umum Syariah semakin tidak efektif dalam mengelola aset perusahaan yang salah satunya adalah aset tak berwujud yang ada perusahaan. Berikut daftar perusahaan yang mengalami penurunan ROA:

\section{Tabel 2}

\section{Data Perbankan Syariah yang Mengalami Penurunan ROA}

\begin{tabular}{clcc}
\hline No & \multicolumn{1}{c}{ Bank Umum Syariah } & Tahun & Return On Assets \\
\hline 1 & PT. Bank Aceh Syariah & $2017-2018$ & $1,92 \%$ menjadi $1,90 \%$ \\
2 & PT. Muamalat Indonesia & $2016-2017$ & $0,14 \%$ menjadi $0,04 \%$ \\
3 & PT. Bank BRI Syariah & $2016-2018$ & $0,61 \%$ menjadi $0,32 \%$ \\
4 & PT. Bank BNI Syariah & $2016-2017$ & $0,98 \%$ menjadi $0,88 \%$ \\
5 & PT. Bank Mega Syariah & $2016-2018$ & $1,80 \%$ menjadi $0,63 \%$ \\
6 & PT. Bank Panin Dubai Syariah & $2016-2017$ & $0,22 \%$ menjadi $-11,23 \%$ \\
\hline
\end{tabular}

Sumber: Data Olahan (2021)

Dalam meningkatkan kinerja keuangan dalam perusahaan menyatakan ada 2 komponen 
besar yang mempengaruhi kinerja keuangan yaitu financial capital dan Modal Intelektual dalam Budihardjo (2016). Dalam financial capital tersebut didalamnya modal fisik yaitu seperti jumlah aset tak bergerak. Tanpa adanya modal fisik ini modal intelektual tidak dapat dijalankan secara optimal dalam perusahaan. Modal Intelektual adalah material yang telah disusun, ditangkap dan digunakan untuk menghasilkan nilai aset yang lebih tinggi. Menurut Pulic (2000) komponen utama dari $\mathrm{VAIC}^{\mathrm{TM}}$ dapat dilihat dari sumber daya perusahaan, yaitu Physical Capital (VACA - Value Added Capital Employed), Human Capital (VAHU - Value Added Human Capital), dan Structural Capital (STVA - Structural Capital Value Added).

VACA membandingkan antara Value Added serta modal fisik yang digunakan (Capital Employed). Penelitian Firmansyah (2014) memperoleh hasil yakni VACA berpengaruh terhadap kinerja keuangan, hal ini didukung penelitian Anrizal (2018) dan Puspitosari dan Surakarta (2016). Namun temuan berbeda ditemukan oleh penelitian Lestari (2017), Achadiani (2016) dan Juliana (2019).

VAHU memberikan informasi mengenai berapa besar terhadap nilai tambah yang diperoleh organisasi bisnis dengan dana tenaga kerja yang dibayarkan. Temuan yang berkaitan dengan VAHU yang berpengaruh terhadap kinerja keuangan seperti penelitian Simarmata dan Subowo (2016), Wijaya dan Wiksuana (2018) dan Puspitosari dan Surakarta (2016). Namun bertentangan dengan penelitian Firmansyah (2014), Anrizal (2018) dan Apriliani (2011).

STVA memberikan kontribusi Structural Capital (SC) dalam menciptakan nilai. Penelitian Achadiani (2016) menemukan hasil dimana STVA memiliki pengaruh terhadap Kinerja Keuangan, hal ini sesuai dengan penelitian Firmansyah (2014) dan Puspitosari dan Surakarta (2016). Berbeda dengan temuan penelitian Wijaya dan Wiksuana, (2018), Anrizal (2018) dan Ritonga dan Andriyanie (2011) menemukan hasil bahwa STVA tidak memiliki pengaruh terhadap Kinerja Keuangan.

Keunggulan bersaing adalah kemampuan, asset, skill, kapabilitas dan lainnya yang memampukan perusahan untuk bersaing secara efektif di dalam industri dalam Sampurno (2010). Dengan adanya konsep Modal Intelektual, maka perusahaan akan mampu menghasilkan keunggulan bersaing yang akan membawa pengaruh terhadap kinerja keuangan perusahaan. Menurut Ferdinand (2003) pada pasar yang bersaing, kemampuan perusahaan menghasilkan kinerja, terutama kinerja keuangan sangat bergantung pada derajat keunggulan kompetitifnya. Hasil penelitian terkait pengaruh keunggulan bersaing memediasi hubungan modal intelektual terhadap kinerja keuangan telah banyak dilakukan seperti Rochmadhona et al., (2018), Deviana (2018) dan Nurhayati et al., (2019)

Berdasarkan uraian latar belakang dan fenomena diatas, maka penelitian ini bertujuan 
untuk meneliti komponen modal intelektual terhadap kinerja keuangan dengan keunggulan bersaing sebagai variabel intervening .

\section{PENGEMBANGAN HIPOTESIS}

\section{Pengaruh Value Added Capital Employed-(VACA) terhadap Kinerja Keuangan}

VACA membandingkan antara nilai tambah (Value Added-VA) dengan modal fisik yang digunakan (Capital Employed-CE). Organisasi bisnis dalam memanfaatkan Capital Employed (CE) akan terlihat lebih baik apabila satu (1) unit Capital Employed-CE dapat memperoleh pengembalian yang tinggi. Organisasi bisnis memperoleh VACA apabila modal yang terpakai lebih kecil tetapi dapat menghasilkan peningkatan terhadap penjualan atau apabila modal yang digunakan meningkat diiringi dengan pula penjualan yang semakin besar pula. Komponenkomponen fisik seperti CEE juga sangat penting dalam meningkatkan kinerja keuangan organisasi bisnis. Kondisi tersebut dikarenakan CEE merupakan komponen dari VAIC ${ }^{\text {TM }}$ yang dapat menggambarkan terkait efisiensi dari modal fisik dalam organisasi bisnis. Didalam modal fisik ada beberapa hal penting yang jika dimanfaatkan dan digunakan dengan efektif dapat memberikan peningkatan terhadap kinerja keuangan, hal tersebut adalah modal finansial dalam Budihardjo (2016).

\section{H1: Terdapat Pengaruh Value Added Capital Employed (VACA) terhadap Kinerja Keuangan.}

\section{Pengaruh Value Added Capital Employed (VACA) terhadap Keunggulan Bersaing}

Capital Employed Efficiency (CEE) yang dapat memeberikan nilai tambah sehingga akan meningkatkan keunggulan kompetitif bagi organisasi bisnis. (Pulic, 2000) mengasumsikan bahwa jika satu (1) unit CE memberikan keunggulan yang lebih banyak dibandingkan organisasi bisnis yang lain, maka organisasi bisnis itu dianggap lebih efektif dalam mengelola CE-nya. apabila hal tersebut dapat dilakukan secara berkesinambungan maka akan memberikan peningkatan pada besarnya keunggulan yang dimiliki organisasi bisnis jika dibandingkan pada organisasi bisnis yang lain.

Penggunaan lebih banyak modal yang digunakan juga memiliki peran penting dalam modal intelektual organisasi bisnis. Karena dari sudut pandang ini menunjukkan kemampuan organisasi bisnis dalam mengelola sumber dayanya. Apabila organisasi bisnis dapat memanfaatkan sumber dayanya dengan lebih hemat maka secara tidak langsung organisasi bisnis akan memperoleh keunggulan kompetitif sehingga dapat bersaing dengan organisasi bisnis lainnya dalam dunia usaha.

H2: Terdapat Pengaruh Value Added Capital Employed (VACA) terhadap Keunggulan 


\section{Bersaing.}

Pengaruh Value Added Capital Employed (VACA) terhadap Kinerja Keuangan dengan Keunggulan Bersaing sebagai variabel intervening

VACA adalah suatu indikator yang menunjukkan bahwa unit modal fisik dapat memberikan atau menciptakan nilai tambah organisasi bisnis. Jika 1 unit modal fisik akan menghasilkan pengembalian yang lebih banyak bagi suatu organisasi bisnis dibandingkan dengan organisasi bisnis yang lain, maka organisasi bisnis tersebut dianggap lebih efektif dalam memanfaatkan modal fisiknya. Oleh karena itu, modal fisik yang dikelola secara efektif maupun efisien merupakan sebagian dari penggunaan modal intelektual dalam organisasi bisnis. Pada modal fisik ada modal keuangan yang mampu memberikan peningkatan terhadap kinerja keuangan yang digunakan dengan efektif. Penggunaan modal keuangan ini dapat memberikan nilai tambah yang dapat meningkatkan keunggulan bersaing organisasi, dimana keunggulan dalam bersaing tersebut dapat meningkatkan kinerja keuangan organisasi bisnis.

H3: Keunggulan Bersaing mampu memediasi hubungan antara Value Added Capital Employed (VACA) dengan Kinerja Keuangan.

\section{Pengaruh Value Added Human Capital (VAHU) terhadap Kinerja Keuangan}

Didalam human Capital terdapat inovasi dan pengetahuan yang dapat memberikan peningkatan terhadap daya saing yang akan menciptakan keunggulan kompetitif bagi organisasi bisnis. teknologi dan informasi Pengetahuan yang baik dapat memberikan peluang sebuah organisasi bisnis untuk menciptakan perpaduan yang baik dari modal tidak berwujud dan berwujud untuk meningkatkan keuangan organisasi bisnis dalam Broking (1996). Pengukuran terhadap human capital yang dimiliki oleh organisasi bisnis yang dikembangkan Pulic dapat dilakukan dengan Value Added Human Capital dalam model Value Added Intellectual Coefficient $\left(\mathrm{VAIC}^{\mathrm{TM}}\right)$.

\section{H4: Terdapat Pengaruh Value Added Human capital (VAHU) terhadap Kinerja Keuangan.}

\section{Pengaruh Value Added Human Capital (VAHU) terhadap Keunggulan Bersaing}

Faktor yang mempengaruhi produksi dalam organisasi salah satunya adalah sumber daya manusia (Human Resources). SDM adalah semua segala sesuatu strategi, kreativitas, dan inovasi yang ada dalam suatu organisasi. Tanpa keberadaan manusia, organisasi adalah bangunan kosong yang tak berpenghuni. Oleh karena itu, Manusia merupakan aset yang penting di sebuah organisasi. Sumber daya manusia ini mengandung pengetahuan dan inovasi atau pengenalan hal-hal baru yang dapat meningkatkan daya saing dan mewujudkan terciptanya 
keunggulan bersaing. Bontis et al., (2015) mengemukakan bahwa pengetahuan (HCE/VAHU) merupakan komponen yang paling penting dalam mewujudkan keunggulan kompetitif terutama di saat era globalisasi ini.

H5: Terdapat pengaruh Value Added Human capital (VAHU) terhadap keunggulan bersaing.

Pengaruh Value Added Human Capital (VAHU) terhadap Kinerja Keuangan dengan Keunggulan Bersaing sebagai variabel intervening

Sumber daya manusia memiliki kedudukan penting dalam kelangsungan hidup organisasi atau organisasi bisnis. Dikarenakan human capital ini merupakan perpaduan antara sumber daya tidak berwujud yang dimiliki oleh setiap individu organisasi. Namun, secara keseluruhan, human capital memiliki kedudukan penting karena merupakan sumber inovasi bagi organisasi bisnis dan sumber aset organisasi bisnis. Tenaga kerja yang memiliki sumber daya manusia yang besar akan memberikan keuntungan yang besar pula bagi organisasi bisnis.

Dalam modal manusia (VAHU) terdapat inovasi serta pengetahuan yang dapat memberikan daya bersaing dan dapat mewujudkan keunggulan kompetitif yang dapat mendorong meningkatnya kinerja keuangan organisasi bisnis.

\section{H6: Keunggulan bersaing mampu memediasi hubungan antara Value Added Human capital (VAHU) dengan kinerja keuangan.}

\section{Pengaruh Struktural Capital Value Added (STVA) terhadap Kinerja Keuangan}

Menurut International Federation of Accountan (IFAC), Struktural Modal adalah kemampuan organisasi bisnis dalam memenuhi proses dan struktur aktivitas organisasi bisnis yang mendukung upaya karyawan untuk menghasilkan kinerja intelektual yang baik dan optimal serta kinerja bisnis secara keseluruhan, seperti: proses manufaktur, sistem operasional organisasi bisnis, filosofi manajemen, budaya organisasi dan semua bentuk kekayaan intelektual lainnya.

Wahdikorin (2010) mengemukakan bahwa modal struktural merupakan faktor pendukung manusia dalam meningkatkan kinerja keuangan pada organisasi bisnis. Semakin besar nilai SCE maka akan semakin besar kontribusi organisasi bisnis dalam membangun struktur dalam membentuk nilai bagi organisasi bisnis dalam Aritonang et al., (2019).

H7: Terdapat pengaruh struktural capital value added (Stva) terhadap Kinerja Keuangan Pengaruh Struktural capital Value Added (STVA) terhadap Keunggulan Bersaing

Komponen Modal Intelektual (VAIC ${ }^{\mathrm{TM}}$ ) diantaranya adalah Structural Capital Value Added (STVA) yang dapat membentuk nilai tambah serts meningkatkan keunggulan kompetitif 
bagi organisasi bisnis. Dalam penelitiannya Kamukama (2013) mengemukakan tentang budaya organisasi, jaringan, serta proses internal yang kuat (Struktural Capital) dapat mentingkatkan efisiensi organisasi bisnis, sehingga dapat membentuk biaya rendah dan kualitas dari produk yang bagus memiliki keunikan di pasar sehingga kemungkinan sulit untuk ditiru oleh organisasi bisnis lain.

\section{Hs: Terdapat pengaruh struktural capital value added (stva) terhadap keunggulan bersaing} Pengaruh Struktural capital Value Added (STVA) terhadap Kinerja Keuangan dengan Keunggulan Bersaing sebagai variabel intervening

Hubungan antara modal struktural dan proses nilai tambah dapat dilihat melalui koefisien modal struktural (STVA). STVA adalah total modal struktural yang diperlukan untuk memperoleh satu (1) rupiah dari Nilai Tambah yang menjadi indikator dalam menciptakan nilai dalam Ulum (2013) STVA memberikan kontribusi terhadap modal struktural dalam menciptakan nilai bagi organisasi bisnis. Jika kontribusinya terhadap nilai human capital sedikit, maka kontribusi SC akan menjadi semakin besar.

STVA merupakan alat yang mendukung manusia dalam memperbaiki kinerja keuangan organisasi bisnis. Manajemen modal struktural (STVA) ini bisa menghasilkan nilai tambah yang dapat meningkatkan keunggulan bersaing organisasi bisnis, keunggulan bersaing ini dapat meningkatkan kinerja keuangan organisasi bisnis.

H9: Keunggulan bersaing mampu memediasi hubungan antara structural capital value added (STVA) dengan kinerja keuangan.

\section{Pengaruh Value Added Modal Intelektual (VAIC TM) terhadap Kinerja Keuangan}

Berdasarkan Teori Berbasis Sumber Daya yang dikemukakan Penrose (1959) menyatakan tentang Pendapat bahwa sumber daya organisasi bisnis yang beragam (heterogen) dan layanan produktif yang berasal dari sumber daya organisasi bisnis akan memberikan sifat kompetitif kepada organisasi bisnis, dalam teori manajemen strategik berkembang bahwa keunggulan kompetitif organisasi bisnisakan mencapai keunggulan apabila memiliki sumber daya yang unggul.

Beberapa peneliti menggunakan VAIC untuk mengukur kinerja Modal Intelektual itu sendiri dan untuk melihat hubungan antara Modal Intelektual dengan kinerja keuangan organisasi bisnis. Hal yang paling penting dalam mengukur kinerja keuangan adalah keuntungan yang dihasilkan oleh organisasi bisnis. Semakin tinggi modal intelektual, semakin tinggi pula pemanfaatan sumber daya organisasi bisnis untuk menghasilkan keuntungan. Semakin baik organisasi bisnis dalam mengelola komponen modal intelektual maka akan 
semakin berpengaruh terhadap aset organisasi bisnis. Oleh karena itu, organisasi bisnis harus memiliki aset yang dimilikinya secara efektif dan efisien yang diukur dengan Return On Assets (ROA).

H10: Terdapat pengaruh Value Added Modal Intelektual (VAIC ${ }^{\mathrm{TM}}$ ) terhadap Kinerja Keuangan.

\section{Pengaruh Value Added Modal Intelektual (VAIC $\left.{ }^{T M}\right)$ terhadap Keunggulan Bersaing}

Menurut Resource Based Theory, keunggulan bersaing dapat tercipta apabila organisasi bisnis dapat mengelola sumber dayanya secara efektif serta efisien. Sumber daya yang unggul dalam aset intelektual organisasi bisnis (Modal Intelektual) akan memberikan keunggulan kompetitif bagi organisasi bisnis. Modal Intelektual (Modal Intelektual) yang terdiri atas modal relasional, manusia, dan structural yang dapat memberikan nilai tambah bagi organisasi bisnis dalam Madhani (2009). Dengan mengelola modal intelektual secara efektif akan memberikan Value Added yang dapat meningkatkan keunggulan kompetitif yang dimiliki oleh organisasi bisnis. Organisasi bisnis yang mampu memanfaatkan modal intelektual dengan benar itu akan sangat mempengaruhi keunggulan kompetitif organisasi bisnis, semakin besar nilai modal intelektual semakin besar pula kompetitif organisasi bisnis.

H11: Terdapat pengaruh value added modal intelektual $\left(\mathrm{VAIC}^{\mathrm{tm}}\right)$ terhadap keunggulan bersaing

Pengaruh Value Added Modal Intelektual (VAIC ${ }^{T M}$ ) terhadap Kinerja Keuangan dengan Keunggulan Bersaing variabel intervening

Menurut Penrose (1959) dalam Resource Based Theory menyatakan bahwa organisasi bisnis akan memiliki keunggulan kompetitif jika mereka dapat mengorganisasikan sumber daya dengan efektif. Sumber daya yang organisasi bisnis miliki khususnya modal intelektual, akan sangat mempengaruhi kinerja organisasi bisnis di waktu yang akan datang. Hal ini terjadi karena ketika suatu organisasi bisnis memiliki modal intelektual, maka dapat membuktikan bahwa organisasi bisnis dapat mengelola sumber daya dengan baik sehingga organisasi bisnis dapat memiliki keunggulan kompetitif dari pengelolaan sumber daya tersebut yang kemudian akan dapat menciptakan kinerja organisasi bisnis. Untuk memimpin keunggulan kompetitif, teori berbasis sumber daya juga menyatakan terkait dengan penggunaan sumber daya yang langka, berharga, tidak dapat disubstitusi, tidak sempurna tetapi dapat mencerminkan keunggulan kompetitif dalam Barney (1991).

H12: Keunggulan bersaing mampu memediasi hubungan antara modal intelektual $\left(\right.$ VAIC $\left.^{\mathrm{TM}}\right)$ dengan kinerja keuangan. 


\section{Pengaruh Keunggulan Bersaing terhadap Kinerja Keuangan}

Organisasi bisnis yang bersaing pada pasar, harus mampu menghasilkan kinerja, terutama dalam kinerja keuangan pada tingkat keunggulan kompetitif yang dimilikinya. Dalam hal tersebut organisasi bisnis dapat memanfaatkan keunggulan kompetitifnya untuk meningkatkan kinerja keuangan organisasi bisnis tersebut dalam Ferdinand (2003). keadaan ini sesuai dengan penelitian Kamukama et al., (2011) dan Libyanita dan Wahidawati (2016) yang menemukan bahwa Modal Intelektual memiliki pengaruh terhadap kinerja keuangan dengan keunggulan kompetitif sebagai variabel intervening.

\section{H13: Terdapat pengaruh keunggulan bersaing terhadap kinerja keuangan.}

\section{METODE PENELITIAN}

Populasi pada penelitian ini yaitu semua bank umum syariah di Indonesia yaitu sebanyak 14 organisasi bisnis. Penarikan sampel yang dilakukan adalah dengan menggunakan teknik Non Probability Sampling. Metode yang digunakan adalah dengan metode Purposive Sampling. Jenis data pada penelitian ini adalah kuantitatif dengan sumber data berupa data sekunder. Data sekunder yang digunakan berupa laporan tahunan yang diterbitkan oleh bank umum syariah melalui website resmi masing-masing pada tahun 2016-2018. Teknik analisis data dalam penelitian ini menggunakan analisis jalur dengan menggunakan model SEM (Structural Equation Modeling) dengan bantuan program warp PLS 7.0.

\section{Definisi Operasional Variabel dan Pengukuran Variabel}

\section{Kinerja Keuangan}

Pengertian kinerja keuangan menurut (Sucipto, 2003) adalah "penentuan ukuran-ukuran tertentu yang dapat mengukur keberhasilan suatu organisasi atau organisasi bisnis dalam menghasilkan laba". Pada penelitian kinerja keuangan diproksikan dengan Return On Asset (ROA).

$$
\text { return on asset }=\frac{\text { laba bersih setelah pajak }}{\text { total aktiva }} \times 100 \%
$$

VACA (Value Added Capital Employed)

VACA membandingkan nilai tambah (VA) dengan ekuitas organisasi bisnis (CE), rasio ini menunjukkan setiap satuan modal yang digunakan terhadap nilai tambah organisasi bisnis. (Ulum, 2013).

$$
\text { VACA }=\frac{\text { Value Added }}{\text { Capital Employeee }}
$$

\section{VAHU (Value Added Human Capital)}

VAHU menunjukkan kontribusi yang dibuat oleh setiap rupiah yang diinvestasikan 
dalam human capital terhadap nilai tambah organisasi bisnis (Ulum, 2013).

$$
\mathrm{VAHU}=\frac{\text { Value Added }}{\text { Human Capital }}
$$

\section{STVA (Structural Capital Value Added)}

STVA memproksikan jumlah modal struktural yang dibutuhkan untuk menghasilkan satu rupiah nilai tambah, adalah indikasi seberapa sukses modal struktural (SC) dalam penciptaan nilai. (Ulum, 2013).

VAIC (Value Added Modal Intelektual)

$$
\text { STVA }=\frac{\text { Structure Capital }}{\text { Value Added }}
$$

Value Added Modal Intelektual (VAIC) demonstrasi kemampuan intelektual organisasi. VAIC adalah hasil dari tiga komponen pengukuran Modal Intelektual.

$$
\text { VAIC }{ }^{\mathrm{TM}}=\mathrm{VACA}+\mathrm{VAHU}+\mathrm{STVA}
$$

Keunggulan Bersaing

Asset Utilization (AU) digunakan untuk mengukur tingkat efisiensi yaitu mengukur kemampuan manajemen bank dalam mengelola aset yang dimiliki untuk menghasilkan pendapatan, baik secara operasional maupun non operasional.

$$
\mathrm{AUC}=\frac{\text { Total Revenue }}{\text { Total Aset }} \times 100 \%
$$

\section{HASIL PENELITIAN DAN PEMBAHASAN}

\section{Hasil Uji Statistik Deskriptif}

Berikut adalah hasil uji statistik deskriptif data penelitian:

\section{Tabel 3}

Hasil Uji Statistik Deskriptif

\begin{tabular}{lccccc}
\hline & N & minimum & maximum & Mean & std. Deviation \\
\hline VACA & 39 &, 07 & 2,37 &, 61 &, 38 \\
VAHU & 39 & 1,04 & 6,25 & 3,53 & 1,14 \\
STVA & 39 &, 04 &, 84 &, 67 &, 16 \\
VAIC & 39 & 1,15 & 8,11 & 4,82 & 1,42 \\
ROA & 39 & $-12,18$ & 8,02 &,- 22 & 3,96 \\
AUC & 39 & 3,12 & 31,73 & 9,93 & 6,11 \\
Valid N (listwise) & 39 & & & & \\
\hline
\end{tabular}

Sumber: Data Olahan SPSS (2020)

Dari tabel 3 diatas, dapat dilihat bahwa variabel Value Added Capital Employee (VACA) mempunyai nilai rata-rata sebesar 0,61 dengan standar deviasi sebesar 0,38. Nilai minimum dari Value Added Capital Employee (VACA) sebesar 0,07 dan nilai maksimumnya sebesar 2,37. Rata-rata value added human capital (VAHU) pada Bank Umum Syariah periode 
2016-2018 sebesar 3,53 dengan standar deviasi sebesar 1,14. Nilai minimum dari sebesar 1,04 dan nilai maksimumnya sebesar 6,25. Variabel Structural Capital Value Added (STVA) memiliki nilai rata-rata sebesar 0,67 dengan standar deviasi sebesar 0,16. Nilai minimum dari Structural Capital Value Added (STVA) adalah 0,04 dan nilai maksimumnya sebesar 0,84. Nilai rata-rata dari Value Added Modal Intelektual (VAIC) sebesar 4,82 dengan standar deviasi adalah 1,42. Nilai manimum dari Value Added Modal Intelektual (VAIC) sebesar 1,15 dan nilai maksimumnya sebesar 8,11 .

Variabel kinerja keuangan yang diproksikan dengan Return On Assets (ROA) merupakan perbandingan antara laba bersih dengan total aktiva. Nilai rata-rata dari Return On Assets (ROA) sebesar -0,22 dengan standar deviasi sebesar 3,96. Nilai minimum Return On Assets (ROA) sebesar -12,08 dan nilai maksimumnya sebesar 8,62. Variabel Keunggulan Bersaing diukur dengan Assets Utilization Capability (AUC) nilai rata-rata dari (AUC) sebesar 9,93 dengan standar deviasi 6,11. Nilai minimum dari Assets Utilization Capability (AUC) sebesar 3,12 dan nilai maksimumnya sebesar 31,73.

\section{Hasil Uji Model Struktural (Inner Model)}

Penilaian struktural (inner model) merupakan uji mengenai kecocokan model (Model Fit), Path Coefficient, dan $\mathrm{R}^{2}$. Goodness of Fit model diukur dengan menggunakan $Q$ - square variabel laten dependen dengan interpretasi yang sama.

\section{Tabel 4}

\section{Q-square Coefficient}

\begin{tabular}{lcc} 
& Variabel & $\boldsymbol{Q}$-square \\
\hline Kinerja Keuangan & 0,680 \\
Keunggulan Bersaing & 0,333 \\
\hline
\end{tabular}

Sumber: Data Olahan WarpPLS 7.0 (2021)

Berdasarkan tabel diatas dapat disimpulkan bahwa model memiliki Predictive Relevance dan fit dengan data dikarenakan nilai $Q$ - square sudah > 0 , dapat dilihat dari nilai $Q$ square variabel kinerja keuangan yaitu 0,680>0 dan juga nilai $Q$ - square variabel Keunggulan Bersaing sebesar 0,333 > 0. Dengan demikian model dikatakan memiliki Predictive Relevance dan fit dengan data.

\section{Tabel 5}

\section{Nilai R-square}

\begin{tabular}{lcc}
\hline & Variabel & R-square \\
\hline Kinerja Keuangan & 0,283 \\
Keunggulan Bersaing & 0,500 \\
\hline
\end{tabular}

Sumber: Data Olahan WarPLS 7.0 (2021) 
Tabel 4.4 menunjukkan nilai R-square untuk variabel kinerja keuangan diperoleh sebesar 0,283 atau 28,3\% dipengaruhi oleh variabel pada penelitian ini sisanya $71,7 \%$ dipengaruhi oleh variabel lainnya. Sedangkan nilai R-square untuk variabel Keunggulan Bersaing sebesar 0,500 atau 50\% dipengaruhi oleh variabel penelitian ini sedangkan sisanya $50 \%$ dipengaruhi oleh variabel lainnya.

\section{Hasil Uji Hipotesis}

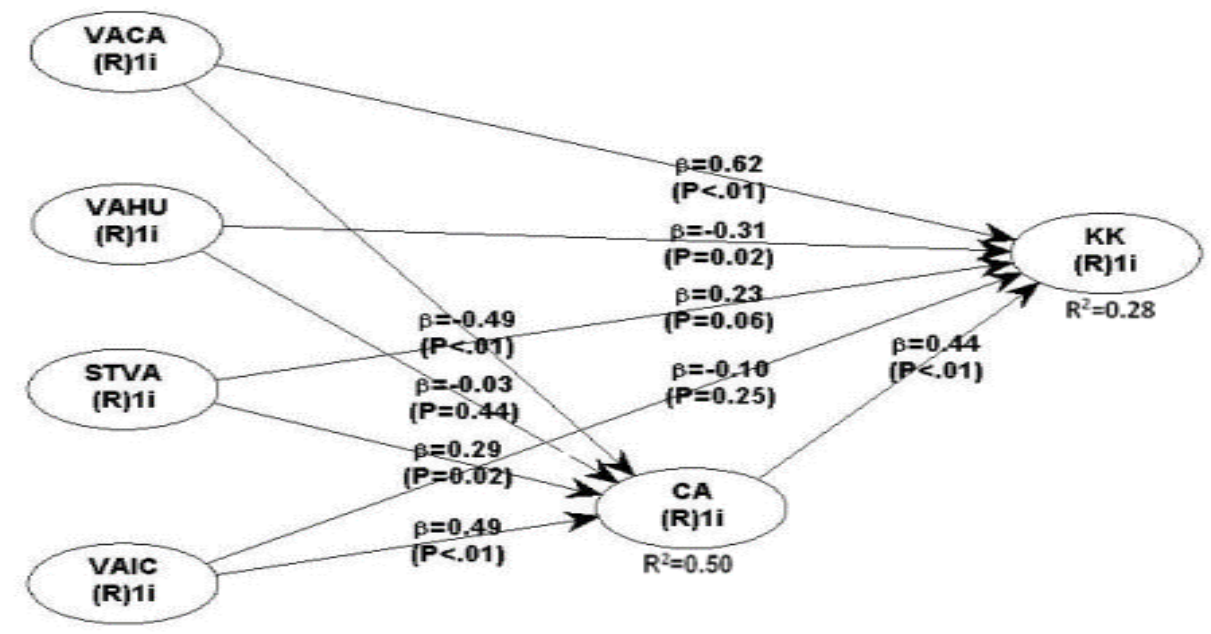

Gambar 1

Hasil Model Penelitian

Sumber: Data Olahan WarpPLS (2021)

Keterangan: VACA : Value Added Capital Employee

VAHU : Value Added Human Capital

STVA : Structure Capital Value Added

VAIC : Value Added Modal Intelektual

CA : Keunggulan Bersaing

KK : Kinerja Keuangan

Tabel 6

Pengaruh Langsung (Direct Effect)

\begin{tabular}{ccccccc}
\hline Kriteria & Variabel & VACA & VAHU & STVA & VAIC & CA \\
\hline Path Coefficient & CA & 0,492 & $-0,026$ & 0,289 & 0,492 & \\
& KK & 0,619 & $-0,306$ & 0,225 & $-0,104$ & 0,436 \\
P-Value & CA & $<0,001$ & 0,435 & 0,024 & $<0,001$ & \\
Effect Size for Path & KK & $<0,001$ & 0,018 & 0,064 & 0,251 & 0,001 \\
& CA & 0,244 & 0,009 & 0,102 & 0,164 & \\
Keterangan & KK & 0,427 & 0,124 & 0,092 & 0,060 & 0,236 \\
& CA & Diterima & Ditolak & Diterima & Diterima & Ditolak \\
& KK & Diterima & Diterima & Ditolak & Ditolak & Diterima \\
\hline
\end{tabular}

Sumber: Data Olahan WarpPLS (2021) 


\section{Tabel 7}

Pengaruh Tidak Langsung (Indirect Effect)

\begin{tabular}{|c|c|c|c|c|c|}
\hline Kriteria & Variabel & VACA & VAHU & STVA & VAIC \\
\hline Path Coefficient & $\begin{array}{l}\text { CA } \\
\text { KK }\end{array}$ & 0,215 & $-0,011$ & 0,012 & 0,214 \\
\hline P-Value & $\begin{array}{l}\text { CA } \\
\text { KK }\end{array}$ & 0,022 & 0,460 & 0,124 & 0,022 \\
\hline Effect Size for Path & $\begin{array}{l}\text { CA } \\
\text { KK }\end{array}$ & 0,148 & 0,005 & 0,052 & 0,125 \\
\hline Keterangan & $\begin{array}{l}\text { CA } \\
\text { KK }\end{array}$ & Diterima & Ditolak & Ditolak & Diterima \\
\hline
\end{tabular}

Sumber: Data Olahan WarpPLS (2021)

\section{Pengaruh Value Added Capital Employee (VACA) terhadap Kinerja Keuangan}

Value Added Capital Employee (VACA) memiliki pengaruh positif terhadap kinerja keuangan dengan p-value sebesar $<0,001$ dengan Path Coefficient sebesar 0,619. Hal ini menunjukkan bahwa Bank Umum Syariah di Indonesia sudah menggunakan sumber daya yang dimilikinya secara optimal, yaitu dana dalam bentuk ekuitas, untuk meningkatskan kinerja keuangannya sehingga ROA meningkat. Hasil penelitian tersebut sejalan dengan penelitian yang dilakukan Aritonang et al., (2019).

\section{Pengaruh Value Added Capital Employee (VACA) terhadap Keunggulan Bersaing}

Value Added Capital Employee (VACA) terdapat pengaruh yang positif terhadap Keunggulan Bersaing dengan P-Value sebesar < 0,001 dengan Path Coefficient sebesar 0,492. Hasil tersebut sesuai dengan Resources Based Theory (RBT) yang beranggapan bahwa organisasi bisnis mampu bersaing dengan organisasi bisnis yang lain, organisasi bisnis memerlukan pengetahuan untuk memanfaatkan aset, baik aset fisik maupun aset intelektual. Hasil penelitian ini memiliki hasil yang sama dengan penelitian yang dilakukan oleh Wang dan Chang (2005), Puspitosari dan Surakarta (2016).

Pengaruh Value Added Capital Employee (VACA) melalui Keunggulan Bersaing terhadap Kinerja Keuangan

Value Added Capital Employed (VACA) melalui Keunggulan Bersaing memiliki pengaruh terhadap Kinerja Keuangan, ditunjukkan dengan nilai p-value sebesar 0,022 dengan Path Coefficient sebesar 0,215. Dalam mengelola modal keuangan yang dapat menghasilkan nilai tambah yang dapat memberikan peningkatkan terhadapkeunggulan organisasi bisnis, dimana keunggulan organisasi bisnis dalam bersaing dapat digunakan untuk mendukung kinerja keuangan organisasi bisnis. Hasil penelitian ini mendukung penelitian yang dilakukan oleh Gunawan (2019), namun berbeda dengan penelitian yang dilakukan oleh Suripto dan Gunawan (2019). 
Pengaruh Value Added Human Capital (VAHU) terhadap Kinerja Keuangan dan Pengaruh Value Added Human Capital (VAHU) terhadap Keunggulan Bersaing

Value Added Human Capital (VAHU) tidak memiliki pengaruh terhadap Keunggulan Bersaing dengan P-Value sebesar 0,435 dengan Path Coefficient dengan nilai r-0,026. Dengan hasil ini dinyatakan bahwa pengetahuan dan keterampilan yang dimiliki Hasil tersebut tidak dapat menyatakan bahwa pengetahuan dan keterampilan yang dimiliki oleh pegawai Bank Umum Syariah cenderung mudah ditiru, sehingga keterampilan serta pengetahuan tersebut dapat mempengaruhi keunggulan kompetitifnya. Hasil penelitian ini mendukung penelitian yang dilakukan oleh Gunawan (2019).

Pengaruh Value Added Human Capital (VAHU) melalui Keunggulan Bersaing terhadap Kinerja Keuangan

Value Added Human Capital (VAHU) melalui Keunggulan Bersaing tidak mempunyai pengaruhterhadap Kinerja Keuangan ditunjukkan dengan p-value sebesar 0,460 dengan Path Coefficient sebesar - 0,011. penelitian yang dilakukan oleh Gunawan (2019) mengatakan manajemen sumber daya manusia tidak mampu memberikan keuntungan untuk organisasi bisnis dibandingkan dengan organisasi bisnis pesaing. Selain itu, pembayaran ini cukup besar namun tidak dapat memberikan peningkatan terhadap kinerja keuangan organisasi bisnis. Hasil penelitian mendukung penelitian yang dilakukan oleh Gunawan (2019) dan Suripto dan Gunawan (2019).

\section{Pengaruh Structural Capital Value Added (STVA) terhadap Kinerja Keuangan}

Structure Capital Value Added (STVA) tidak memiliki pengaruh terhadap kinerja keuangan dengan p-value sebesar 0,064 dengan Path Coefficient sebesar 0,225. organisasi bisnis belum dapat memanfaatkan modal struktural yaitu proses kegiatan organisasi bisnis dan strukturnya yang dapat meningkatkan kinerja bisnis secara keseluruhan, seperti filosofi manajemen, sistem operasional organisasi bisnis, budaya organisasi yang dimiliki organisasi bisnis dalam menghasilkan keunggulan bersaing yang bermanfaat bagi kinerja keuangan organisasi bisnis dalam Salim dan Karyawati (2013). Penelitian ini mendukung penelitian yang dilakukan oleh Anrizal (2018) dan Ramadhanty dan Azib (2018).

\section{Pengaruh Structural Capital Value Added (STVA) terhadap Keunggulan Bersaing}

Structural Capital Value Added (VACA) memiliki pengaruh yang positif terhadap Keunggulan Bersaing dengan p-value sebesar 0,024 dengan Path Coefficient sebesar 0,289. Organisasi bisnis yang memiliki Structural capital yang baik dalam hal sistem, prosedur, mekanisme kerja, struktur organisasi, dan budaya organisasi bisnis akan menjadikan organisasi 
bisnis lebih memiliki manajerial yang lebih baik dari pada kompetitor. Hasil penelitian ini mendukung penelitian yang dilakukan de Pablos (2004).

\section{Pengaruh Structural Capital Value Added (STVA) melalui Keunggulan Bersaing terhadap}

\section{Kinerja Keuangan}

Keunggulan Bersaing tidak dapat memediasi hubungan Struktural Capital Value Added (STVA) terhadap kinerja keuangan ditunjukkan dengan nilai p-value sebesar 0,124 dengan path coefficient sebesar - 0,013. Barney (1991), menyatakan bahwa meskipun sumber-sumber keunggulan kompetitif seperti teknologi, skala ekonomi, database, organisational charts dan sebagainya mampu menciptakan nilai, namun pendapat yang didasarkan pada pandangan ini menyatakan bahwa sumber-sumber keunggulan kompetitif tersebut cenderung semakin mudah untuk ditiru. Penelitian ini mendukung penelitian yang dilakukan oleh Gunawan (2019) dan Suripto dan Gunawan (2019).

\section{Pengaruh Value Added Modal Intelektual (VAIC) terhadap Kinerja Keuangan}

Value Added Modal Intelektual (VAIC) tidak memiliki pengaruh terhadap kinerja keuangan dengan p-value sebesar 0,251 dengan Path Coefficient sebesar-0,104. Hal ini menunjukkan bahwa beberapa modal intelektual yang telah dikeluarkan oleh organisasi bisnis belum secara langsung mempengaruhi upaya organisasi bisnis mendapatkan ROA yang lebih baik. Hasil penelitian ini mendukung penelitian yang dilakukan oleh Wahdikorin (2010) dan Ciptaningsih (2013).

\section{Pengaruh Value Added Modal Intelektual (VAIC) terhadap Keunggulan Bersaing}

Value Added Modal Intelektual (VAIC) memiliki pengaruh positif terhadap Competitive Advatage dengan P-Value sebesar < 0,001 dengan Path Coefficient sebesar 0,492. Hasil juga mendukung dengan Resources Based Theory (RBT) yang beranggapan bahwa Keunggulan kompetitif tercipta organisasi bisnis yang bersahabat dapat mengelola sumber daya secara efektif dan efisien. Sumber daya unggul yang ada pada kekayaan intelektual organisasi bisnis (Modal Intelektual) dapat memberikan keunggulan bersaing bagi organisasi bisnis. Hasil penelitian ini mendukung penelitian yang dilakukan Anisah (2016) dan Libyanita dan Wahidawati (2016).

\section{Pengaruh Value Added Modal Intelektual (VAIC) melalui Keunggulan Bersaing terhadap}

\section{Kinerja Keuangan}

Value Added Modal Intelektual (VAIC) melalui Keunggulan Bersaing terhadap Kinerja Keuangan memiliki pengaruh positif terhadap Kinerja Keuangan dengan P-Value sebesar 0,022 dengan Path Coefficient sebesar 0,214. Hasil ini menemukan bahwa organisasi bisnis yang 
dapat mengelola modal intelektual dengan efektif akan mampu mewujudkan keunggulan bersaing berupa yang membedakannya dengan organisasi bisnis pesaing sehingga dapat meningkatkan kinerja keuangan bagi organisasi bisnis dan dapat bersaing secara kuat.Hasil penelitian ini sesuai dengan penelitian yang dilakukan oleh Kamukama (2013), Barney (1991) dan Tovstiga et al., (2011).

\section{Pengaruh Keunggulan Bersaing terhadap Kinerja Keuangan}

Keunggulan Bersaing memiliki pengaruh positif terhadap kinerja keuangan dengan pvalue sebesar 0,001 dengan path coefficient sebesar 0,436. Suatu organisasi bisnis dengan keunggulan bersaing dan daya saing yang besar akan lebih dikenal oleh pelanggan dan masyarakat luas. Dengan demikian organisasi bisnis dapat lebih mudah menjual produknya ke masyarakat dan mendapatkan pendapatan yang besar. Peningkatan nilai dari pendapatan akan menunjukkan peningkatan pula kinerja organisasi bisnis. Hasil penelitian ini sesuai dengan penelitian yang dilakukan Kamukama (2013) dan Libyanita dan Wahidawati (2016).

\section{SIMPULAN}

Berdasarkan analisis dan pembahasan pada bagian sebelumnya, maka dapat ditarik kesimpulan bahwa VACA berpengaruh positif terhadap kinerja keuangan, VAHU berpengaruh negatif terhadap kinerja keuangan serta STVA dan VAIC tidak berpengaruh terhadap kinerja keuangan. Selanjutnya, penelitian ini membuktikan bahwa VACA berpengaruh negatif terhadap Keunggulan Bersaing, VAHU tidak berpengaruh terhadap Keunggulan Bersaing dan STVA dan VAIC memiliki pengaruh yang positif terhadap Keunggulan Bersaing, sedangkan Keunggulan Bersaing juga berpengaruh positif terhadap kinerja keuangan. Penelitian ini juga menemukan bahwa Keunggulan Bersaing berperan dalam memediasi pengaruh VACA dan VAIC terhadap kinerja keuangan, sedangkan Keunggulan Bersaing tidak memediasi pengaruh VAHU dan STVA terhadap kinerja keuangan.

Dari penelitian yang dilakukan peneliti menemukan keterbatasan yaitu (1) Penelitian ini hanya terbatas pada Bank Umum Syariah yang terdaftar pada Otoritas Jasa Keuangan di Indonesia. (2) Penelitian ini hanya menggunakan periode penelitian tiga tahun yaitu tahun 2016, 2017 dan 2018. (3) Penelitian ini hanya menggunakan rasio Return On Assets (ROA) sebagai proksi kinerja keuangan. (4) Penelitian ini hanya menggunakan Value Added Capital Employed (VACA), Value Added Human Capital (VAHU), Structural Capital Value Added (STVA) dan Value Added Modal Intelektual (VAIC) sebagai variabel independen.

Berdasarkan hasil penelitian serta hal-hal yang terkait dengan keterbatasan penelitian, maka dapat diberikan saran (1) Penelitian selanjutnya diharapkan mengganti atau memperluas 
sampel penelitian seperti pada sektor keuangan, sektor manufaktur dan sektor jasa yang terdaftar di Bursa Efek Indonesia. (2) Penelitian selanjutnya diharapkan bisa menambah periode penelitian menjadi 5-10 tahun agar meningkatkan keakuratan hasil. (3) Penelitian selanjutnya diharapkan memproksikan pengukuran lain yang digunakan untuk mngukur variabel kinerja keuangan seperti Return On Equity (ROE), Return On Investment (ROI), dan Net Profit Margin (NPM) serta rasio keuangan lainnya. (4) Penelitian selanjutnya dapat mempertimbangkan variabel independen lain yang mempengaruhi variabel dependen, seperti Modal Intelektual Disclosure, Good Corporate Governance, Corporate Social Responsibility Disclosure, Dana Pihak Ketiga, dan Struktur Modal.

\section{REFERENSI}

Achadiani, M. (2016). Pengaruh Elemen-Elemen Modal Intelektual Terhadap Kinerja Keuangan Pada Perusahaan Bumn Yang Listing Di Bursa Efek Indonesia (Bei) Periode 2012-2014. Repository Universitas Widyatama. https://repository.widyatama.ac.id/xmlui/handle/123456789/7604?show=full

Anisah, R. N. (2016). Pengaruh Modal Intelektual Terhadap Kinerja Keuangan Perusahaan Dengan Keunggulan Kompetitif Sebagai Variabel Intervening. Jurnal Akuntansi \& Investasi, 17(2), 215-226.

Anrizal, S. Y. (2018). Pengaruh Modal Intelektual Dengan Pendekatan Islamic Banking Value Added Intellectual Coefficent (IB-VAIC) Terhadap Kinerja Keuangan Bank Umum Syariah Di Indonesia. STIE Perbankan Indonesia, 1(1), 8-15.

Apriliani, R. (2011). Pengaruh Modal Intelektual Terhadap Kinerja Keuangan Perusahaan. Eprints Undip.

Aritonang, Q. A. S., Muharam, H., \& Sugiono. (2019). Pengaruh Modal Intelektual Terhadap Kinerja Keuangan Perusahaan. Jurnal Profita, 12(3), 433. https://doi.org/10.22441/profita.2019.v12.03.006

Barney, J. (1991). Firm Resources And Sustained Keunggulan Bersaing. Journal Of Management, 17, 99-120.

Bontis, N., Janošević, S., \& Dženopoljac, V. (2015). Modal Intelektual in serbia's hotel industry. International Journal of Contemporary Hospitality Management, 27(6), 1365-1384. https://doi.org/10.1108/IJCHM-12-2013-0541

Broking, A. (1996). No TitleModal Intelektual. Core Asset For The Third Millenium Enterprise. Thompson Bussines Press.

Budihardjo, A. (2016). Knowledge Management: Efektif Berinovasi Meraih SUkses. Prasetiya Mulia Publishing.

Ciptaningsih, T. (2013). Uji Pengaruh Modal Intelektual terhadap Kinerja Keuangan BUMN yang Go Public di Indonesia. Jurnal Manajemen Teknologi, 12(3), 330-348. https://doi.org/10.12695/jmt.2013.12.3.7 
de Pablos, P. O. (2004). Measuring and reporting structural capital: Lessons from European learning firms. Journal of Modal Intelektual, 5(4), 629-647. https://doi.org/10.1108/14691930410567059

Deviana, D. A. (2018). Analisis Pengaruh Modal Intelektual terhadap Financial Performance dengan Keunggulan Bersaing sebagai variabel intervening. Jurnal Universitas Muhammadiyah Surakarta, 1(1), 1-8.

Ferdinand, A. (2003). Keunggulan Diferensiasif dan Kinerja Pemasaran. Jurnal Bisnis Strategi, $12,1-18$.

Gunawan, M. (2019). Pengaruh Modal Intelektual terhadap Kinerja Keuangan Pada Perusahaan Manufaktur dengan Keunggulan Bersaing sebagai variabel intervening. Jurnal Online Mahasiswa (JOM) Universitas Riau Bidang Ilmu Ekonomi.

Helfert, E. A. (1996). Teknik Analisis Keuangan. Erlangga.

Hidayat, D. (2018). ( Studi Pada Perusahaan Pertambangan Subsektor Pertambangan Minyak Dan Gas Bumi Yang Terdaftar Dibursa Efek Indonesia Periode 2013-2016 ). 62(1), 3644.

Ikatan Akuntan Indonesia. (2007). Standar Akuntansi Keuangan. Salemba Empat.

Juliana, S. (2019). Analisis Pengaruh Modal Intelektual terhadap Kinerja Keuangan Bank Umum Syariah di Indonesia. E-Skripsi Universitas Andalas. http://scholar.unand.ac.id/43169/

Kamukama, N. (2013). Modal Intelektual: Company's invisible source of Keunggulan Bersaing. Competitiveness Review, 23(3), 260-283. https://doi.org/10.1108/10595421311319834

Kamukama, N., Ahiauzu, A., \& Ntayi, J. M. (2011). Keunggulan Bersaing: Mediator of Modal Intelektual and performance. Journal of Modal Intelektual, 12(1), 152-164. https://doi.org/10.1108/14691931111097953

Lestari, H. S. (2017). Pengaruh Modal Intelektual Terhadap Kinerja. XXI(03), 491-509.

Libyanita, M., \& Wahidawati. (2016). Pengaruh Modal Intelektual Terhadap Kinerja Keuangan. 5, 1-19.

Madhani, P. (2009). Resources Based View: Concept And Practice. Icfai University Press.

Nurhayati, E., Arifin, B., \& Mulyasari, W. (2019). Pengaruh Modal Intelektual Terhadap Kinerja Keuangan Di Industri Perbankan Dengan Compotitive Advantage Sebagai Variabel Intervening. Tirtayasa EKONOMIKA, 14(1), 1-24.

Penrose, E. (1959). The Theory Of The Growth Firms. Basil Blackwell \& Mott Ltd.

Pulic, A. (2000). VAIC- An Accounting Tool For IC Management. International Journal Of Technology Management, 20.

Puspitosari, I., \& Surakarta, I. (2016). Pengaruh Modal Intelektual terhadap Kinerja Keuangan 
pada Sektor Perbankan The Impact of Modal Intelektual on Banking Sectors Financial Performance. 43-53.

Ramadhanty, H. D., \& Azib. (2018). Pengaruh Modal Intelektual terhadap Kinerja Keuangan Perusahaan Perbankan Umum Syariah yang Terdaftar di Otoritas Jasa Keuangan ( OJK ) Tahun 2017-2018. 4, 586-589.

Ritonga, K., \& Andriyanie, J. (2011). PENGARUH MODAL INTELEKTUAL TERHADAP KINERJA KEUANGAN (Pada Perusahaan LQ45 yang Terdaftar di Bursa Efek Indonesia). Jurnal Riset Akuntansi Dan Bisnis, 3(2), 467-481.

Rochmadhona, B. N., Suganda, T. R., \& Cahyadi, S. (2018). The Keunggulan Bersaing between Modal Intelektual and Financial Performance of Banking Sector in ASEAN. Jurnal Keuangan Dan Perbankan, 22(2), 321-334.

Salim, \& Karyawati. (2013). Pengaruh Modal Intelektual terhadap Kinerja Keuangan. Journal Of Business And Entrepreneur, 1.

Sampurno. (2010). Manajemen Stratejik: Menciptakan Keunggulan Bersaing yang Berkelanjutan. Gadjah Mada University Press.

Simarmata, R., \& Subowo. (2016). Pengaruh Modal Intelektual Terhadap Kinerja Keuangan Dan Nilai Perusahaan Perbankan Indonesia. Accounting Analysis Journal, 5(1), 1-9. https://doi.org/10.15294/aaj.v5i1.9748

Sucipto. (2003). Penilaian Kinerja Keuangan. Jurnal Akuntansi Universitas Sumatera Utara, 6.

Suripto, \& Gunawan, J. (2019). Modal Intelektual Determinant Towards Company's Keunggulan Bersaing and Performance and Its Impact on Company's Values. International Journal of Business and Law, 19(5), 145-163.

Tovstiga, G., Tulugurova, E., Tovstiga, G., \& Tulugurova, E. (2011). study Modal Intelektual practices : a four-region study. https://doi.org/10.1108/14691930910922905

Ulum, I. (2013). Model Pengukuran Kinerja Modal Intelektual Dengan Ib-Vaic Di Perbankan Syariah. INFERENSI. Jurnal Penelitian Sosial Keagamaan, 7(1), 185-206.

Wahdikorin, A. (2010). Pengaruh Modal Intelektual Terhadap Kinerja Keuangan Perusahaan Perbankan Yang Terdaftar Di Bursa Efek Indonesia (BEI) Tahun 2007-2009. Skripsi Publikasi Universitas Diponegoro.

Wang, W. Y., \& Chang, C. (2005). Modal Intelektual and performance in causal models. Evidence from the information technology industry in Taiwan. Journal of Modal Intelektual, 6(2), 222-236. https://doi.org/10.1108/14691930510592816

Warren, C. S., Revee, J. M., \& Duchac, J. E. (2013). Principles Of Accounting-Indonesia Adaptation. Salemba Empat.

Wijaya, W. A., \& Wiksuana, I. G. B. (2018). Pengaruh Modal Intelektual Terhadap Kinerja Keuangan Pada Subsektor Industri Hotel , Restoran Dan Pariwisata Fakultas Ekonomi 
dan Bisnis Universitas Udayana ( UNUD ), Bali , Indonesia ABSTRAK PENDAHULUAN Penggambaran mengenai kondisi finansial sebuah p. E-Jurnal Manajemen Unud, $7(2)$ 701-729. https://doi.org/10.24843/EJMUNUD.2018.v7.i02.p01\%0AISSN

Firmansyah, I. (2014). Pengaruh Modal Intelektual terhadap Profitabilitas, Nilai Pasar, Pertumbuhan, Actual Return Pada Perusahaan yang tercatat di Bursa Efek Indonesia. Jurnal EKonomi Dan Bisnis, 50-59. 